\title{
Western Europe and its Historical Engagement in the Balkans
}

\author{
Ylber Sela, PhD \\ Bekim Maksuti, PhD \\ Driton Kuçi, MA
}

\section{Doi:10.5901/mjss.2015.v6n2s5p238}

\section{Abstract}

The European continent and in particular the Western Europe have always been involved in a range of events and developments. History has always shown and made us aware that the Western Europe in particular has been the cradle and the instigator of many positive developments, as well as many destructive conflicts and wars in the past. Geographically, this region has undergone the great challenges long time ago and it now cherishes the benefits of the mutual organization and cooperation, whereas other regions tend to approach and join the European values, namely the united democratic Europe and its organization as foreseen within the European Union. If we would only take a look at the Balkans, we would see that besides geographically, it is also closely related to Europe politically and economically. The historical period to be considered in this paper is that after World War II, namely the post-Cold War period, after the big changes in central Europe, and the eastern and southern Europe, i.e. the Balkans. The Western Europe, after the declaration of the end of Cold War in particular, will be actively involved in all major events and developments in the Balkans. The turbulences that fell upon this region will present a challenge and often put on the state of alert the western world and the organizations and institutions which emerged as a result of their consistent cooperation. There is no doubt that the Western Europe will have a key role in the ending of hostilities and conflicts, a key role in the development and the realization of strategic aspirations of the Balkan countries in their endeavors to join the NATO Alliance, the EU and other international organizations.

Keywords: Europe, Balkan Region, conflicts, cooperation, integration.

\section{Introduction}

Looking at the map of Europe we can see the large diversity of many geographic, social, economic, political, security and other specific divergences. Historically through the centuries, "the Old Continent", as many scientist like to call Europe, was the main locomotive for development, different ongoing processes, wars and conflicts. However, this contains different events and occurrences for this particular part or region of Europe.

Europe as celery, through the time perspective, not always had the same developments or even the same problems. Part of the continent occasionally was partially under the control or occupation of different Emperies such Roman, Ottoman or Russian in periods when they took under control different parts of European soil.

Main goal of this paper is to address the problem or issue of different approaches of Europe to the developments in the Balkan region or part of it. So, if we want to do that in a proper way, we should look forward to address the main topics for European engagement observing them from different perspectives. Thus, we can establish three ways of explanation and analyzing of the topic of this paper.

Firstly, the historic aspect presents one of the inalienable issue through which we must pass. We don't want to go into so many details and analyze historic data and fact sheets but the only thing we want to do is to address the main historic developments where we can find the connection between Europe and Balkan as a part or region.

Through the centuries the Balkan was on "apple of discord" between the interests of grand powers. Some critics tend to call the Balkans as a "civilizations crossroad" or some of them "gunpowder keg". We recognize the rights of the groups for such a qualification ${ }^{1}$. But, if we make one timeline retrospective what had happen in the Balkans with or without European engagement ${ }^{2}$, we can find many events, stories and developments. Wars and conflicts were just a segment of the issues but the most influential one. The Balkan as a region occasionally was under war, or under different

${ }^{1}$ Ismail Kadare, Predrag Simic, Ljubomir Frckovski, Ylber Hysa, "Ballkani i Jugut", Onufri 2001.

2 When we spoke for European engagement into Balkan we think and would like to express the influence, interference and commitment of the countries of Western Europe in all the developments and events. This is the main intent firstly and later to combine with the engagement of NATO, EU and other European organization. 
crises and other conditions not even close to peace. Many international peace Conferences such us in Paris, London, Bucharest and others are more than a prove for this engagement. The Balkan Wars in the 20-th century provide the right answer of that how this region can be influenced or can influence, to trigger conditions and events with huge size or global world developments such as First World War. Most of the critics share the opinion that the Balkans and all the Balkans circumstances initiated and triggered the start of First World War. This war expanded and imperfect wars as the Balkan First and Second War. Honestly, this period was one of the most difficult in the history of Balkan. Stepping out from one of the largest timeless occupation (Ottoman Empire), the interests of the independent countries, big powers and new born countries was totally different and some time even unreal.

Europe at that time was represented with England and France vs. Prussia (Germany) and Austro-Hungary, always took into consideration the nonpermanent alignment of Tsar Russia and totally different positions of the Turkish Empire. Although, the Balkans in this context of different interests and influences, will be hard a subject of a hard dispute for the common relation between relevant actors as I mentioned before, sometimes even the traditional relations between them will be challenged. All those circumstances will provoke many agreements and alliances just to prevent each other on having an advantage in the position of international relations. Many of those alliances and agreements will be just piece of paper and never not been implemented in practice.

So the dissolution of Ottoman Empire left enough space for engagement and influence of others and especially Russia, who directly and indirectly influenced and supported Serbia and Greece in their efforts to expand their state borders. This issue will also be very interesting for the rest of the Europe especially for the France, Great Britain and other powers.

First World War expressed how much is the Balkan region interesting for "the special interests" and how it can be "an arena" where big powers crosswalk their military, economic and political outwitting to each other just to grab as much as they can and be in advanced position?

The Balkans region, even during the efforts for establishing the League of Nations, was also a part of the agenda for many discussions between the main world players because of its potential for instability, relations and wars.

Honestly speaking, even the positive approach towards the Balkans will not be able to change anything in historical context in the Balkans and between the countries of this region. Hostilities grew stronger and stronger, many disputes characterized the relations between the countries and we can conclude that the ongoing processes in this region do not provide straight perspectives. Maybe this is a very strong statement and not so realistic or positive approach, but we can elaborate on this later.

Our intent is not to address and explain what happened and predict the future of the Balkan region through the scope of the European perspective, but to show what the engagements actually were during in the course of different timeframe. An analysis of various events and developments where Europe was the driver of significant efforts with positive approach is more then we showed before. The Second World War can prove the conclusions that we drove before. The battles of this war also affected the Balkan region. The main developments during the war were affected by the countries from the Balkans. Some allied with the Nazi ideologies and some with the western European countries and the USA.

All the events during the World War II and after that were top priority in agenda of the western powers (USA, UK and France), and directly influenced many results of the war and post war processes. Honestly speaking the termination of the World War Two in the Balkans resulted in the formation of Yugoslavia as a sovereign federal country composed with republics and other parts and included the larger part of the region of the Balkans.

After the World War II, Yugoslavia became a leading country of Non-Aligned Movement during post war period, and the greater part of the rest of the world divided itself into two ideologies -Western and Eastern that was more than a reason for the initiation of the Cold War4.

The launch of Marshal Plan for reconstruction of Europe after war and the support from the USA excluded the Balkans as a region and a part of South-Eastern Europe due to many reasons but mostly because of the neutral status of Yugoslavia and the intention not to belong and be part of any strict ideology regardless of whether it comes from the east or the west.

We can freely state that the Balkan region was one of the most important issues and collision among the West and the East even during the period of Cold War. The ambition for enlargement of both groups confronted in the Balkan region.

3 Ylber Sela, "The Balkans Yesterday, Today and Tomorrow: On Behalf of the 100 Anniversary of the Balkans Wars 1912-2012", Dictus Publishing, Jun 3, 2013.

${ }_{4}^{4}$ Denko Maleski, "Politicki Esei”, Edicija Makedonija, Skopje 2012. 
The foundation of the UN and the NATO and later the European Coal and Steel Community (EU) was mostly based on interests and developments, a fact that we can analyze as a topic in this paper. Everything we have said so far was in this spirit and describes the European engagement during different timeframe and various historic perspectives.

In the following text we address more aspects of the engagement of Europe into Balkan.

Secondly, we will analyze issues and processes of enlargement and integration in the main international organization such as NATO and EU through the scope of Balkans.

Analyzing the establishment of the NATO, we can conclude that the first and the main policy of this military-political organization is the collective security. From this aspect we can say that the Balkan region rested between the silent conflict of the East and West.

The establishment of the NATO and its geostrategic positioning did not include countries from the Balkan Peninsula or their neighborhood (excluding Italy). But the influence of the Eastern predominant ideology (the one of the USSR and the partner countries from the Warsaw Pact), in the Balkans determined the quick reaction of the NATO and the US interests to find partners from this region or close enough for the purpose of closing some strategic exits to the Mediterranean and Middle East. This issue was resolved during the first NATO enlargement in 1952 when Greece and Turkey became full-fledged members. The admission of Turkey was a strategic issue for opening an exit towards the Middle East and closing the doors to Russia and it became of very high importance to NATO, Western and the US policy.

This was only one way of perspective of looking to the ongoing problem such was the Greece-Turkey dispute and lots of centuries old antagonism. This was a message to the all that peace interests are more than just having an ambition for influence. It was also a clear message to the East to leave the Balkan out of the overlapping interests of the East and the West.

If we take into consideration the aspect of borders and influences we can see that Hungary was forced into the Eastern ideologies. Also the same destiny shared Bulgaria and Romania, and other countries close to the Balkan region and neighbors to Russia.

Europe and its organization played an active role in many processes during the Cold War. Couple of in-country revolutions were suppressed by Russia and the Warsaw Pact being characterized as "not obedience" of some members of the Pact.

On other hand the foundation of first model of today's EU also played a very active role especially in the economy. So, if the NATO was political-military organization, the European Coal and Steel Community was something else and its main objective was the cooperation in economy and other fields related to this issue.

The time challenge also touched both of these organizations, something that we already mentioned before. A future that cannot be predicted, the problem of not enough resources, freedom of movement, trade, disputes, conflicts and other issues directly impacted the policy of these organizations and their acts. The Balkan region was not immune of those challenges. Directly or indirectly the West and Europe applied their expanding interests to this region. We witnessed and analyzed the first enlargement of NATO and what it mean in the context of the Cold War.

The New era started with the end of the Cold War. This was the main reason for shifting of the policy of the NATO but also the EU. The fall of Berlin Wall as a symbol of the Cold War, the reunification of Germany, the revolution in USSR, the dissolution of former Czechoslovakia and Yugoslavia were the main events that marked the 90'. So, parallel to those challenges began an adoption of western policy in accordance to the needs and upcoming processes such were the integration of the regions and countries and their stepping out from the so called umbrella of East ideologies.

The enlargement of the EU in the post Cold War period with the countries from the Central, East or South Europe ( Malta, Cyprus, Estonia, Latvia, Lithuania, Poland, Czech Republic, Slovakia, Slovenia, and Hungary in 2004) expressed how fast the policy can change and the engagement of Europe in some parts can change. Except This "big bang" enlargement included only Slovenia and other Balkan countries were excluded. The next enlargement in 2007 with Bulgaria and Romania was something that seemed impossible for many reasons ${ }^{5}$. This process of integration of the countries into EU was preceded by the process of enlargement and integration of the NATO. Most of those countries were members of the NATO. In 1999 three joined NATO and in 2004 seven countries including Bulgaria, Romania and Slovenia as countries from the Balkan became NATO members. In 2009, Albania and Croatia became full-fledged members of NATO.

Thirdly, the dissolution of Yugoslavia triggered the open hostilities between the new independent countries. Open conflicts and disputes between the newly formed independent countries and the part of Yugoslavia that wanted to preserve the status and conditions from before, produced a lot of problems and headaches for Europe and provoked its encouragement engagement in the Balkans. Setting up a two-side problem, efforts were made to find an acceptable

${ }^{5}$ Also Croatia became a full member of EU in 01.07.2013. 
solution for all parties involved in the conflict and make real the aspiration of becoming a full member in NATO and EU.

Historically we saw that Europe was engaged in the Balkan for long time, at the beginning to be an active role player after the end of the Cold War and to influence developments in the region. The launching of different tools from NATO and EU according to the situation in region clarifies the role and commitment of Europe. Partnership for Peace, International Crises Group, Process of Association and Stabilization were the main initiatives that could address the Balkan. Lots of conferences and agreements according to the different events and developments directly will be agenda of the Europe and their institutions and organizations.

The process of integration of the countries from the Balkan region in the NATO and the EU means conducting hard reforms in many social, political, economic and security areas. The leadership of those countries should work harder on the affirmation of the benefits and values of those expectations from the EU and NATO fulfilling membership criteria.

So, in this part we analyzed in what were the manners of the Europe's engagement in the region looking from juridical and policy perspective.

Different countries from the region had different status about issues for the relations and membership in the NATO and EU. Now we would like to emphasize where we are as a R. of Macedonia and where the whole region is. As the country became independent after the dissolution of Yugoslavia, the R. of Macedonia started a relation with Europe and both of the organizations right after the referendum for independence. Becoming a member of the Initiative Partnership for Peace and initiating the process of preparation (reforms) for membership in NATO we started to implement the Membership Action Plan (16-th cycle) and we are still conducting the transformation and reforms of the security sector ${ }^{6}$.

In the spirit of EU membership in 2001 we signed the Stabilization and Association Agreement and in 2005 we became a candidate for full-fledged member country. Both of the processes went through many challenges and difficulties. If we just mention the crises and conflict during the 2001 and the difficult process of reconciliation and reconstruction according to the Ohrid Framework Agreement ${ }^{7}$, we can conclude that the country was under permanent engagement of Europe and its institutions and organizations. So, those European efforts one more time showed that they are still interested and helpful to the region with many tools and policies.

\section{Conclusion}

As we mentioned during the whole paper we divided the engagement of the Europe in three pillars. First we elaborate how and in what kind Europe was engaged with the Balkan region and countries into in historic aspect. With the full right we can conclude that Europe and their initiatives for this region were only on way to influenced to the events and developments. It's more than facts how the Europe and its powers during the different time framework they drive some of the processes in not proper way. They even make a wrong efforts staying away or taking a side in some of the developments or events. So all those what we said are well known historic described facts.

Secondly, we stop with the challenges of foundation and formation of organization and institution in Europe such us NATO and EU directly showed how they was included and engaged into main events and developments into Balkan region and their countries. Making a parallel between processes of integration and enlargement common with numerous challenges during the different time and Europe and organization (NATO and EU), influenced directly or indirectly in some of the disputes or event just to prevent more bloodshed during different conflicts.

Thirdly, trying to present engagement of Europe into Balkan, we compare this issue with the positive reflection of the processes of enlargement and integration vis-a-vi reforms and preparation of the countries for the full membership into European Union and NATO Alliance. Intent of this perception was based into so many initiatives and tools using by those organizations in advance to help and prepare those countries to meet criteria's.

Summary based on what we conclude before, we can say that Europe during the different time had different approach and different level of commitment according to developments and events into Balkan. Going from one extreme to another Europe was positioning about the issue and engagement to Balkan.

\footnotetext{
${ }^{6}$ Annuals Rapports from the European Commissions and North Atlantic Council - NATO about process of integration of the countries from southeast Europe.

7 Ohrid Framework Agreement was achieved on 13.08.2001 in Ohrid under suspicions of EU, NATO and US representatives with four main political leaders in Macedonia after conflict between government security forces and National Liberation Army -military formation of the local Albanians
} 


\section{References}

Fabrizio Tassinari, "Why Europe Fears Its Neighbors", ABC-CLIO, 2009,

Roger D. Petersen, "Western Intervention in the Balkans: The Strategic Use of Emotion in Conflict", Cambridge University Press, Sep 30, 2011,

Janusz Bugajski, "Western Balkans Policy Review 2010", CSIS, 2010,

Dana H. Allin, "NATO's Balkan Interventions", Routledge, Aug 27, 2014,

Tom Gallagher, "The Balkans in the New Millennium: In the Shadow of War and Peace", Routledge, Apr 28, 2005,

Sharyl Cross, Savo Kentera, Radovan Vukadinovic, R. Craig Nation, "Shaping South East Europe's Security Community for the TwentyFirst Century: Trust, Partnership, Integration", Palgrave Macmillan, May 7, 2013,

Ismail Kadare, Predrag Simic, Ljubomir Frckovski, Ylber Hysa, "Ballkani i Jugut", Onufri 2001,

Denko Maleski, "Politicki Esei", Edicija Makedonija, Skopje 2012,

Blerim Reka, Ylber Sela, "Hyrje në të drejtën e Unionit Evropian", Arbëria Design, 2007

Ylber Sela, "The Balkans Yesterday, Today and Tomorrow: On Behalf of the 100 Anniversary of the Balkans Wars 1912-2012", Dictus Publishing, Jun 3, 2013,

Ylber Sela, Bekim Maksuti, "FUTUR ENLARGEMENT OF THE EU-THE CHALLENGE CALL WESTERN BALLKAN AND TURKEY", Paper prepared for the Euroacademia International Conference The European Union and the Politicization of Europe Vienna, 8 - 10 December 2011. 